\title{
POVINNÉ SUBJEKTY MAJÍ PŘI POSKYTOVÁNÍ INFORMACÍ POVINNOST SPOLUPRACOVAT $S$ ŽADATELI
}

\author{
ADAM JARE $\check{S}^{1}$
}

Soud: $\quad$ Ústavní soud České republiky

Věc: $\quad$ III. ÚS 3339/20

Datum: $\quad$ 1. 7. 2021

Dostupnost: nalus.usoud.cz

\section{1. ÚVOD}

Právo na informace je zásadně bezplatné. Povinné subjekty jsou však v souvislosti s poskytováním informací oprávněny žádat úhradu nákladů spojenou s pořízením kopií, opatřením technických nosičů dat a s odesláním informací žadateli. Povinný subjekt může také žádat úhradu za mimořádně rozsáhlé vyhledání informací. ${ }^{2}$

Úprava zák. o svobodném př́stupu $\mathrm{k}$ informacím je poměrně stručná a v praxi vyvolává značné množství otázek. Různé aspekty této zákonné úpravy jsou tak řešeny $\mathrm{v}$ odborné literatuře a judikatuře. To platí i pro stanovení výše úhrady nákladů. Spory nemusí vyvolávat požadavek na úhradu nákladů např́íklad při pořízení kopií, kdy bude úhrada stanovena jednoduše s ohledem na počet kopírovaných stran a sazbu za jednu stranu dle sazebníku úhrad vydaného povinným subjektem. Spory však vyvolává

JUDr. Adam Jareš, doktorand katedry občanského práva Fakulty právnické Západočeské univerzity v Plzni, kontaktní e-mail: ajares@kpo.zcu.cz.

2 § 17 odst. 1 zákona č. 106/1999 Sb., o svobodném přístupu k informacím (dále jen „zák. o svobodném přístupu k informacím"). 
náhrada nákladů za mimořádně rozsáhlé vyhledávání informací. Náhradu za jednu hodinu vyhledávání informací sice bude také stanovena v sazebníku, žadatel však nemusí souhlasit s délkou tohoto vyhledávání tvrzenou povinným subjektem či se samotným podřazením činnosti povinného subjektu pod neurčitý právní pojem „mimořádně rozsáhlé vyhledávání informací“.

Dalším rozhodnutím do mozaiky rozhodovací praxe ke svobodnému přístupu $\mathrm{k}$ informacím je anotované rozhodnutí. V něm se Ústavní soud zabýval otázkou omezení práva na informace žadatele požadavkem povinného subjektu na úhradu téměř 26 milionů korun za mimořádně rozsáhlé vyhledávání informací a otázkou vázanosti povinného subjektu žádostí o poskytnutí informací. Ústavní soud v anotovaném rozhodnutí nastínil poměrně př́sné požadavky na povinné subjekty př̌i vyřizování žádostí o informace.

\section{PROCESNÍ HISTORIE}

Žadatel, datový novinář serveru iROZHLAS.cz Jan Cibulka ${ }^{3}$ požádal podle zák. o svobodném přístupu $\mathrm{k}$ informacím povinný subjekt, Policejní prezidium České republiky, o seznam údajů o všech trestných činech evidovaných za posledních pět let předcházejících podání žádosti, a to v rozsahu: unikátní identifikátor trestného činu, čas spáchání trestného činu, čas přijetí oznámení o trestném činu, typ oznamovatele, typ trestného činu (například podle takticko-statistické klasifikace používané Policií České republiky), místo spáchání trestného činu (adresa, GPS souřadnice), způsobená škoda či jiný následek a informace o užití zbraně.

Povinný subjekt nejprve žádost odmítl, protože podle něj by bylo nutné požadované informace nově vytvořit. ${ }^{4}$ Na vytváření nových informací se

3 KUBIŠTOVÁ, Dominika. Ústavní soud dal datovému novináři za pravdu. Policie nemůže chtít miliony za informace o kriminalitě. In: iROZHLAS.cz [online] 8. 7. 2021 [cit. 2021-07-14] Dostupné z: https://www.irozhlas.cz/zpravy-domov/policie-data-o-kriminalite-ustavni-soud-novinar-nalez_2107080924_dok

4 Celé rozhodnutí je dostupné v článku: Kočí, Petr. Policie vysvětluje, proč chtěla 25 milionů za data: zaměstnala by prý bývalé policisty. In: iROZHLAS.cz [online] 7. 9. 2016 [cit. 2021-07-14] Dostupné z: https://www.irozhlas.cz/zpravy-domov/policie-vysvetluje-procchtela-25-milionu-za-data-zamestnala-by-pry-byvale-policisty_201609072157_jcibulka 
totiž povinnost poskytovat informace nevztahuje. ${ }^{5}$ Ministerstvo vnitra jako nadřízený orgán však toto rozhodnutí zrušilo.

Povinný subjekt následně požadoval v souvislosti $\mathrm{s}$ vyřízením žádosti úhradu z důvodu mimořádně rozsáhlého vyhledání informací. ${ }^{6} \mathrm{~V}$ odůvodnění tohoto požadavku uvedl, že vyhledání každého žádaného údaje o trestném činu si vyžádá alespoň 30 sekund času. Vyhledání informací mělo mít dvě fáze. $\mathrm{V}$ první by byly informace vyhledány a ve druhé by muselo být pro každý trestný čin posouzeno, zda poskytnutím kombinace údajů nebudou poškozena práva třetích osob či probíhající vyšetřování, přičemž tuto činnost nebylo možné učinit strojově. Na základě této úvahy pak měl povinný subjekt dojít $\mathrm{k}$ závěru, zda některé $\mathrm{z}$ žádaných údajů nemají být odděleny a jejich poskytnutí odepřeno. Podle povinného subjektu totiž údaje vztahující se ke konkrétnímu času a místu umožňovaly v některých případech identifikaci osob zúčastněných na trestním řízení. Trestných činů bylo v předmětném období evidováno 1543 485. ${ }^{7}$ Za vyhledávání a poskytnutí informací v celkovém rozsahu 102899 hodin při sazbě 251 Kč dle sazebníku úhrad Ministerstva vnitra pak povinný subjekt požadoval úhradu ve výši 25827649 Kč.

Žadatel požadovanou částku neuhradil, proto povinný subjekt žádost odložil. Tento postup předpokládá $\S 17$ odst. 5 zák. o svobodném př́stupu $\mathrm{k}$ informacím, přičemž odložení žádosti je rozhodnutím dle $\S 65$ zákona č. 150/2002 Sb., soudní řád správní, a proti takovému rozhodnutí je možné brojit správní žalobou. ${ }^{8}$ Proti rozhodnutí podal žadatel k Městskému soudu v Praze správní žalobu, kterou soud zamítl jako nedůvodnou. ${ }^{9}$ Žadatel ne-

5 § 2 odst. 4 zák. o svobodném přístupu $\mathrm{k}$ informacím.

6 Žádat úhradu nákladů umožňuje povinným subjektům $\S 17$ odst. 1 zák. o svobodném přístupu k informacím.

7 Bod 5 a 23 anotovaného rozhodnutí či bod 6 a 8 rozsudku Nejvyššího správního soudu ze dne 24. 9. 2020, č. j. 3 As 46/2019-54.

8 Srov. usnesení rozšířeného senátu Nejvyššího správního soudu ze dne 21. 9. 2010, č. j. 2 As 34/2008-90, či rozsudek Nejvyššího správního soudu ze dne 21. 6. 2017, č. j. 6 As 326/2016-32.

9 Rozsudek Městského soudu v Praze ze dne 18. 1. 2019, č. j. 6 A 248/2016-73. 
byl úspěšný ani s kasační stížností proti rozsudku Městského soudu a Nejvyšší správní soud ji zamítl. ${ }^{10}$

Žadatel se dále bránil ústavní stížností, ve které namítal porušení práva na informace a práva na soudní ochranu zaručené Listinou základních práv a svobod. ${ }^{11}$ Argumentoval především tím, že povinný subjekt měl zvolit takový postup, který umožní informace alespoň z části poskytnout, když požadovaná částka úhrady nákladů představuje zásadní ekonomickou bariéru $\mathrm{k}$ přístupu $\mathrm{k}$ informacím. Soudy měly podle něj rozpoznat excesivnost tohoto požadavku. V ústavní stížnosti žadatel také směřoval na to, že Policie ČR je povinna vysvětlovat, proč se jí například nedaří eliminovat určité druhy trestné činnosti v konkrétní lokalitě apod., přičemž ve veřejné diskusi k těmto otázkám spatřuje naplňování práva obětí trestné činnosti na účinné vyšetřování. ${ }^{12}$

\section{BYLO POŽADAVKEM NA ÚHRADU NÁKLADŮ ZASAŽENO DO PRÁVA NA INFORMACE ŽADATELE?}

Ústavní soud se nejprve zabýval posouzením toho, zda povinný subjekt požadavkem na úhradu nákladů za mimořádně rozsáhlé vyhledávání informací ve výši téměř 26 milionů Kč a následným odloženým žádosti neporušil žadatelovo právo na informace.

Své úvahy započal odkazem na dřívější rozhodovací praxi. Povinný subjekt může provést kvalifikovaný odhad nákladů na vyhledání informací například tak, že vyhledá část informací, a na základě toho odhadne potřebný čas pro vyhledání zbylých informací. ${ }^{13}$ Ústavní soud upozornil na to, že možnost zpoplatnit poskytnutí informace nemá být zneužívána či nadužívána. Z tohoto důvodu jsou na povinné subjekty kladeny poměrně vysoké nároky na odůvodnění stanovení úhrady, a to včetně důkladného a věrohodného popisu jednotlivých úkonů, které s poskytnutím informací či jejich

\footnotetext{
10 Rozsudek Nejvyššího správního soudu ze dne 24. 9. 2020, č. j. 3 As 46/2019-54.

11 Stěžovatel konkrétně namítal porušení čl. 17 odst. 4 a čl. 36 odst. 1 a 2 Listiny základních práv a svobod.

12 Body 16 až 19 anotovaného rozhodnutí.

13 Nález Ústavního soudu ze dne 21. 5. 2019, sp. zn. I. ÚS 1083/16.
} 
vyhledáváním souvisí. Povinné subjekty by tak měly dbát na přezkoumatelnost odůvodnění stanovení úhrady za poskytnutí informací nejen co do její výše, ale i účelnosti a racionality. ${ }^{14}$

Podle Ústavního soudu však v posuzované věci vyplynulo, že kvalifikovaný odhad provedený povinným subjektem neměl žádný reálný základ. ${ }^{15}$ Pochybnosti soudu také vyvolal rozsah zpoplatněných informací. $\mathrm{V}$ předchozích řízeních opakovaně zaznělo, že selekci údajů nelze provést strojově, požadované informace je nutné individuálně podrobit zkoumání v kontextu s ostatními údaji a dalšími okolnostmi každého př́ípadu a až následně je možné je oddělit od údajů, jejichž poskytnutí žadateli musí být v souladu se zákonem odepřeno. Tyto závěry však podle soudu neměly žádnou oporu ve spisech a nelze $\mathrm{z}$ nich dovodit opodstatněnost stanovené úhrady. ${ }^{16}$

K tomu Ústavní soud dále dodal, že správní orgány zvolily neodůvodněně zřejmě ten nejkomplikovanější možný způsob, jak se $s$ žádostí vypořádat. Jejich postup při stanovení úhrady proto shledal nejen nepřezkoumatelným, ale rovněž značně iracionálním. ${ }^{17}$

Z předchozích řízení a vyjádření povinného subjektu navíc vyplynulo, že disponuje informačním systémem, ze kterého lze jednoduchým postupem získat sestavu 7 z 8 žadatelem požadovaných údajů. Soud pak považoval za zjevné, že některé z takto snadno a rychle dohledatelných typů údajů nemají minimálně samy o sobě žádný potenciál mařit účinné vyšetřování či ohrozit práva třetích osob. U těchto údajů či u jejich vzájemné kombinace podle soudu postačí poměrně jednoduchá a rychlá úvaha, zda je jejich poskytnutím možné zasáhnout do jiného konkurujícího ústavně garantovaného základního práva či veřejného zájmu. To však považoval za běžný úkon povinného subjektu, který nelze hodnotit za součást mimořádně rozsáhlého

14 Bod 33 anotovaného rozhodnutí, či např. rozsudek Nejvyššího správního soudu ze dne 21. 6. 2017, č. j. 6 As 326/2016-32.

15 Bod 43 anotovaného rozhodnutí. Ve správním spisu měl být podle soudu například založen úřední záznam z provedeného vyhledávání.

16 Bod 45 anotovaného rozhodnutí.

17 Bod 46 anotovaného rozhodnutí. 
vyhledávání informací. ${ }^{18} \mathrm{~K}$ tomu soud uzavřel, že povinný subjekt paušálně bránil žadateli v přístupu ke všem požadovaným informacím, aniž k tomu minimálně u některých ze žádaných informací měl jakýkoliv racionální důvod. $^{19}$

Povinný subjekt již ve svém původním rozhodnutí o odmítnutí žádosti připustil, že u některých druhů trestných činů by bylo zřejmě možné žadateli poskytnout požadované údaje bez negativních důsledků poskytnutí, resp. zveřejnění informace. Podle soudu měl povinný subjekt s touto možností dále pracovat a využít ji k alespoň částečnému vyhovění žádosti. ${ }^{20}$

\section{JE POVINNÝ SUBJEKT VÁZANÝ ŽÁDOSTÍ O POSKYTNUTÍ INFORMACE?}

Ústavní soud se dále zabýval otázkou vázanosti povinného subjektu žádostí o poskytnutí informace.

Zák. o svobodném přístupu k informacím stanoví, že informace se poskytují zveřejněním nebo na základě žádosti, ve formátech a jazycích podle obsahu žádosti o poskytnutí informace a způsobem podle obsahu žádosti. ${ }^{21}$

Nejvyšší správní soud tak v předchozím řízení dovodil, že „činnost povinného subjektu je vymezena rozsahem žádosti o poskytnutí informací a ten je obsahem žádosti $v$ zásadě vázán (...) Není jeho úlohou, aby za žadatele domýšlel, jaké informace - jiné, než výslovně požadované v žádosti, avšak v určité míře podobné těm požadovaným - lze poskytnout tak, aby určitý záměr žadatele byl splněn. “22

S tímto závěrem však Ústavní soud nesouhlasil. Konstatoval vázanost povinného subjektu obsahem a rozsahem žádosti pouze v tom smyslu, že je povinen požadavky žadatele vyřídit bezezbytku. Nemusí je však vyřídit všechny stejným způsobem. Podle něj tak měla být část informací po-

\footnotetext{
18 Bod 47 anotovaného rozhodnutí.

19 Bod 50 anotovaného rozhodnutí.

20 Bod 51 anotovaného rozhodnutí.

${ }^{21}$ Srov. § 4 a § 4a zák. o svobodném přístupu k informacím.

22 Bod 39 rozhodnutí Nejvyššího správního soudu ze dne 24. 9. 2020, č. j. 3 As 46/2019-54.
} 
skytnuta bezodkladně a bez požadavku na úhradu vynaložených nákladů, část mohla být zpoplatněna a část odmítnuta.

\section{ZÁVĚR ÚSTAVNÍHO SOUDU}

V návaznosti na výše uvedené pak Ústavní soud formuloval závěry $\mathrm{k}$ postupu Policejního prezidia ČR ve věci předmětné žádosti o poskytnutí informace, které zároveň zobecňuje i pro ostatní povinné subjekty. Předně konstatuje, že povinný subjekt „má být profesionálem znalým práva, který má žadatele procesem poskytování informací provést tak, aby jim bylo $v$ maximální míre vyhověno“. Má tak „hledat způsoby maximálního vyhovění podané žádosti a nikoliv di̊vody, jak jejímu vyhovění zabránit “. ${ }^{23}$

Soud také upozorňuje na to, že je úlohou povinných subjektů informovat veřejnost $\mathrm{v}$ co nejširší možné míře, $\mathrm{k}$ čemuž mají využít všech procesních nástrojů, které jsou jim k dispozici. Při vyřizování žádostí o informace mají povinné subjekty postupovat podle základních zásad činnosti správních orgánů. ${ }^{24}$ Při jejich spojení s principem neformálnosti charakteristickým pro poskytování informací lze totiž s žadateli velice efektivně kooperovat. Se stěžovatelem měl podle soudu povinný subjekt neformálně komunikovat a informovat ho o povaze nutných úkonů, upozornit na rozsah i dostupnost požadovaných informací a zjistit, zda jeho zájem a o jaké informace trvá. Tímto způsobem bylo možné vzájemně dospět k modifikaci původní žádosti tak, aby bylo možné stěžovateli alespoň částečně vyhovět. $^{25}$

Ústavní soud tak dospěl k závěru, že bylo porušeno žadatelovo právo na informace podle čl. 17 odst. 1, 4 a 5 Listiny základních práv a svobod a zrušil předcházející rozhodnutí jak Městského soudu v Praze, ${ }^{26}$ tak Nejvyššího správního soudu. ${ }^{27}$

\footnotetext{
23 Bod 61 anotovaného rozhodnutí.

24 Vyjma základních zásad činnosti správních orgánů zák. o svobodném přístupu k informacím užití správního řádu předpokládá jen pro stanovené úkony (Srov. § 20 odst. 4 zák. o svobodném přístupu k informacích).

25 Bod 62 anotovaného rozhodnutí.

26 Rozsudek Městského soudu v Praze ze dne 18. 1. 2019 č. j. 6 A 248/2016-73.

27 Rozsudek Nejvyššího správního soudu ze dne 24. 9. 2020 č. j. 3 As 46/2019-54.
} 


\section{REFLEXE ROZHODNUTÍ}

Veřejná správa má být pojímána jako služba veřejnosti. Poskytování informací vztahující se $\mathrm{k}$ jejich působnosti patří mezi základní činnosti orgánů veřejné moci. Například Nejvyšší správní soud dříve konstatoval, že v našem civilizačním prostoru je poskytování informací obecným standardem demokratických právních států, které zároveň vyžaduje určité finanční zatížení orgánu veřejné správy. ${ }^{28}$

Bez řádného informování veřejnosti nemůže fungovat kontrola veřejné správy ze strany veřejnosti. Data poskytovaná veřejnosti na základě žádosti o poskytnutí informací anebo zveřejněním také mohou mít informační ale i jinou hodnotu při jejich dalším zpracování, a to nejen pro samotného žadatele, ale rovněž i pro širokou veřejnost. ${ }^{29}$

Žadatelem byl $\mathrm{v}$ předmětné věci navíc novinář, který může plnit úkoly nebo poslání dozoru veřejnosti či roli tzv. „společenského hlídacího psa“ ve smyslu nálezu Ústavního soudu ze dne 17. 10. 2017, sp. zn. IV. ÚS 1378/16. ${ }^{30}$ Dle tohoto nálezu má taková osoba za splnění dalších podmínek $^{31}$ nárok na širší rozsah informací než žadatel, který všechny tyto podmínky nenaplní. Před vydáním anotovaného rozhodnutí také vyšlo najevo, že obdobný soubor informací již povinný subjekt poskytl jinému žadateli. Mělo jít o seznam všech trestných činů za delší časové období (1996 až 2013) a s podstatně větším rozsahem údajů. Rozsah poskytnutých údajů byl užší pouze v údaji o místu spáchání trestného činu (v tomto př́ípadě nebyla poskytnuta GPS souřadnice, ale pouze identifikace obvodního oddělení Policie ČR) a v údaji o čase oznámení trestného činu (v tomto případě byl poskytnut datum zahájení trestního řízení). ${ }^{32}$ Postup povinného subjektu, kte-

\footnotetext{
${ }^{28}$ Rozsudek Nejvyššího správního soudu ze dne 27. 6. 2007, č. j. 6 As 79/2006-58, publikovaný ve Sbírce rozhodnutí Nejvyššího správního soudu pod poř. č. 1342/2007.

${ }^{29}$ MÍŠEK, Jakub. Data veřejného sektoru, In: POLČÁK, Radim a kol. Právo informačních technologii. Praha: Wolters Kluwer ČR, 2018, s. 347.

30 Nález byl publikován ve Sbírce nálezů a usnesení Ústavního soudu pod poř. č. 188/2017.

31 Účelem vyžádání informace je přispět $\mathrm{k}$ diskusi o věcech veřejného zájmu, informace se týká veřejného zájmu a informace existuje a je dostupná.

32 Bod 25 anotovaného rozhodnutí.
} 
rým v konečném důsledku nebyly žadateli poskytnuty žádné informace, tak je podle mého názoru těžko obhajitelný.

Jako nepřiměřené se mi $\mathrm{v}$ obecném měřítku však jeví konstatování Ústavního soudu o tom, že povinný subjekt má být profesionálem znalým práva. To je jistě pravda u povinných subjektů například typu ministerstev, krajů, hlavního města Prahy či územně členěných statutárních měst, většiny veřejných institucí nebo právě i např́klad Policejního prezidia ČR. Na druhou stranu, povinným subjektem jsou všechny územně samosprávné celky. ${ }^{33}$ Obcí je v České republice $6258 .{ }^{34}$ Medián počtu obyvatel v obci je 442, obcí s celkovým počtem obyvatel nižším než 100 obyvatel je $415 .^{35}$ V České republice je tedy velké množství obcí, které nebudou mít v obecním úřadu k dispozici profesionální úředníky. Běžně se lze setkat se situacemi, kdy žádost o poskytnutí informací vyřizuje ve svém volném čase starosta, jelikož obec nemá pro výkon funkce starosty ani uvolněného člena zastupitelstva. ${ }^{36}$ To však nemění nic na tom, že by povinné subjekty měly při poskytování informací na žádost $\mathrm{s}$ žadateli spolupracovat, nikoliv poskytování informací bránit.

Povinné subjekty tak mají primárně hledat způsob, jak žadatelům vyhovět, nikoliv jak jim $\mathrm{v}$ př́stupu $\mathrm{k}$ informacím bránit. To lze dovodit i z recentního rozhodnutí Nejvyššího správního soudu ze dne 5. 2.2021, č. j. 1 As 281/2020-42. Z něj vyplývá, že $v$ případě žádosti o poskytnutí více informací by měl povinný subjekt žadatele informovat také o tom, že budeli žádat pouze o určité informace, měl by je obdržet bezplatně. Informace se tak mají poskytovat aktivně, bezplatně a přiměřená úplata požadována až jako poslední možnost. ${ }^{37}$

33 Viz. § 2 odst. 1 zák. o svobodném př́istupu k informacím.

34 Český statistický úřad. Počet obyvatel v obcích k 1. 1. 2021 [online]. czso.cz [cit. 2021-0717]. Dostupné z: https://www.czso.cz/csu/czso/pocet-obyvatel-v-obcich-k-112021

35 Na základě údajů tamtéž. Při výpočtu nebyly brány v úvahu městské části a městské obvody a bylo vycházeno $\mathrm{z}$ počtu obyvatel $\mathrm{v}$ hlavním městě Praze a celých územně členěných statutárních měst.

36 Zde vycházím i z vlastních zkušeností při podávání žádostí o informace v souvislosti s opatřováním dat o místních referendech proběhlých v letech 2014 až 2016.

37 Bod 30 rozhodnutí Nejvyššího soudu ze dne 5. 2.2021, č. j. 1 As 281/2020-42. 
Pro povinné subjekty $\mathrm{z}$ anotovaného rozhodnutí tedy vyplývá především nutnost spolupráce $s$ žadateli. $V$ prŕpadech, kdy povinné subjekty skutečně dojdou $\mathrm{k}$ závěru, že poskytnutí informací bude možné až na základě mimořádně rozsáhlého vyhledávání, jehož úhrada by mohla zcela znemožnit poskytnutí všech požadovaných informací, měly by s žadateli neformálně komunikovat. Mohou žadatele informovat o svém postupu a nutných úkonech, upozornit na rozsah i dostupnost požadovaných informací a zjistit, zda má stále zájem na poskytnutí informací, resp. zda trvá jeho zájem na poskytnutí veškerých původně požadovaných informacích. ${ }^{38}$ Takovým způsobem může dojít $\mathrm{k}$ úpravě původní žádosti o informace a alespoň některé informace mohou být poskytnuty řádně a bez nutnosti úhrady. Zároveň tak bude naplněn charakter činnosti veřejné správy jako služby veřejnosti a vyhověno požadavku na její vstřícnost a zdvořilost. ${ }^{39}$ Pokud tyto požadavky nebudou ze strany povinných subjektů plněny, může to mít i širší dopady. Jak totiž konstatuje Ústavní soud v anotovaném rozhodnutí, „[f]rustrace žadatelů o informace, jsou-li vystaveni nezákonným a ve svém důsledku až protiústavním praktikám veřejné správy, aniž by pak dosáhli nápravy alespoň ve správním soudnictví, se následně stává zdrojem neduvěry a zbytečného napětí ve společnosti vi̊či ní. “40 Tomu se povinné subjekty mohou pokusit zabránit mimo jiné $\mathrm{i}$ tím, že budou při vyřizování žádosti o informace vycházet $\mathrm{z}$ principu otevřenosti veřejné správy a budou se snažit žadatelům vycházet co možná nejvíc vstříc.

Toto dílo lze užít v souladu s licenčními podmínkami Creative Commons BY-SA 4.0 International (http://creativecommons.org/licenses/by-sa/4.0/legalcode).

\footnotetext{
38 Jak vyplývá z bodu 62 anotovaného rozhodnutí.

39 § 4 odst. 1 zákona č. 500/2004 Sb., správní řád.

40 Bod 66 anotovaného rozhodnutí.
} 